\title{
Financial Inclusion and Performance to Mediate the Effect of Banking and Tax Regulation on the Success of Small and Medium Enterprises in Indonesia
}

Submitted 11/03/20, $1^{\text {st }}$ revision 08/05/20, $2^{\text {nd }}$ revision 07/06/20, accepted 15/08/20

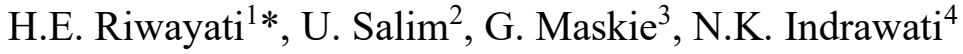 \\ Abstract:
}

Purpose: The research is to analyse the influence of banking and tax regulation that is mediated by financial performance and inclusion of business actors and moderated social responsibility to business success.

Design/methodology/approach: The sample used in this research is Small and Medium Enterprises in Wijirejo batik Village, Pandak District, Bantul Regency, and Yogyakarta, Indonesia. The census sampling technique method was used. The population is amounted to 76 batik business actors. The method of analysis is Wrap-PLS 5.0.

Findings: The results showed tha implementation of banking and tax regulation for small and medium business actors has a number of positive consequences to success of the business involved. Among them regulation of banks through the determination of rate interest on credit, the ease of credit application and the speed of credit process supported by good business management and financial knowledge (financial inclusion) is a good determinant factor in increasing capital, business scale, profit and business management. Tax regulation through the determination of tax rate, ease of tax access, simplification of tax procedure and transparency regarding taxes supported by good business management and financial knowledge (financial inclusion) become the determinant factor in increasing capital, business scale, profit and business management.

Practical implications: The results are interesting from the theoretical and practical aspect to be applied for the financial inclusion.

Originality/Value: The paper contains a formalized approach to the success of Small and Medium Enterprises in Indonesia.

Keywords: Financial inclusion, regulation, business tax.

JEL Code: G14, G19.

Paper Type: Research article.

\footnotetext{
1*Faculty of Economics and Business, Perbanas Institute, Indonesia, e-mail: hedwigis.esti@perbanas.id

${ }^{2}$ Faculty of Economics and Business, Brawijaya University, Indonesia, e-mail: ubud@ub.ac.id

${ }^{3}$ Faculty of Economics and Business, Brawijaya University, Indonesia, e-mail:ghozali@ub.ac.id

${ }^{4}$ Faculty of Economics and Business, Brawijaya University, Indonesia, e-mail: nurkhusniyahindrawati@yahoo.com
} 


\section{Introduction}

The programs and activities undertaken by the Government of Indonesia to develop Small and Medium Enterprises (SME) sector have been very encouraging. Increasing the role and business activities of SME sector is seen especially since the era of economic and financial crisis in 1997. At the time of the restructuring process of corporate sector and SMEs that took place slowly, the SME sector was able to show the growing development and even able to support the national economic growth. The role played by SME sector is expected to continue as governments and stakeholders have a clear reference to the factors that influence the sustainability of SME sector (Widayani et al., 2019). According to Hudson et al. (2001), and Alimusa (2019) the success of small and medium enterprises (SMEs) is influenced by two main factors namely external factors and internal factors. Internal factors include aspects of human resources (owners, managers, and employees), financial aspects, technical aspects of production, and marketing aspects. While external factors consist of government policy, socio-cultural and economic aspects, and the role of related institutions such as government, universities, private, and nongovernmental organizations.

Small and Medium Enterprises in Indonesia often face problems to advance which can be grouped in two factors that are internal and external factors (Munizu, 2010; Widayani et al., 2019). Internal factor problems include low quality of human resources from knowledge, skill, experience, work ethic, and lack of mature entrepreneurship. Other problems faced by SMEs are weakness in technology mastery, limited market information and management impact on low productivity and overall quality management.

The government role towards empowerment of SMEs through various policies issued can affect the sustainability of SMEs (Hudson et al., 2001; Munizu, 2010). According to Hudson et al. (2001), and Munizu (2010) the role of government is an external factor that can affect the performance of SMEs. According to Eniola and Entebang (2015), Ahiawodzi and Adade (2012), government policies in the form of banking regulation have a significant positive effect on the success of SMEs. In contrast to Obasan and Arikewuyo (2012), the existence of banking regulation negatively affects the performance and sustainability of SMEs. While the research of Chen (2006) obtained the result that banking regulation by facilitating SME of easy access to credit to the banking does not affect the performance and success of SMEs.

Government policy through tax regulation is also a factor affecting the performance and success of SMEs. In a country, taxes are an important source of funds for economic development and social services. Taxation by the government is a common problem faced by SMEs. According to Atowadi and Ojeka (2012), Adebisi and Gbegi (2013), they state that between taxes and the ability to sustain and expand SMEs business have a negative relationship. SMEs are often faced with the issue of high tax rates, the imposition of various types of taxes, taxes that have many 
regulations and lack of proper education about tax related issues. According to Adebisi and Gbegi (2013), Natalia and Alexandr (2018) in some developing countries that most affect the activities of SMEs can even hamper the development of its business is a matter of taxation. Ameyaw et al. (2016) states that in relation to government policies on taxes, the imposition of taxes on SMEs should be clearly calculated. Government taxation for SMEs needs to be adjusted to the size and profitability of SMEs. In addition it should consider other factors that may limit the progress of SMEs. Research by Ameyaw et al. (2016), found an association between tax policies with the success of SMEs.

Performance of SMEs is one of the factors that can affect the success of a business. According to Hudson et al. (2001), Munizu (2010), and Widayani et al. (2019) the performance of SMEs is a work process to generate job performance. There are three dimensions as indicators of SME performance, motivation of business owner, management ability and shared vision (Munizu, 2010). Based on the results of the researches by Shah et al. (2011), Mashenene and Rumanyika (2014), and Shuban et al. (2014) the better the performance of SMEs the faster SMEs will achieve success, SMEs performance has a significant positive effect on the success of SMEs. In contrast to the results of Hashi and Krasniqi (2010) which states that the performance of SMEs have a significant negative effect on the success of SMEs.

The financial inclusion of SMEs by Terzi (2015), is one factor that can influence the success of SMEs. Financial inclusion is one of the programs for financial literacy, especially in order to improve the ability of the community in using financial services to obtain direct impact from financial institutions (Alaaraj and Bakri, 2020). According to Terzi (2015) the increasing financial inclusion of SMEs actors can contribute positively to the success of SMEs that ultimately improve the financial stability of a State.

The success of Small and Medium Enterprises (SMEs) is a condition that shows business growth. Business growth can be measured by sales growth, capital, labour, market and profit growth (Hudson et al., 2001; Munizu, 2010; Subhan et al., 2014; Folorunso et al., 2016; Ndesaulwa, 2016; Alimusa, 2019). According to Subhan et al. (2014) the main factors affecting the success of small and medium enterprises (SMEs) consists of 2 factors, namely internal and external factors of SMEs.

Internal factors include managerial skills, experience of owner or manager, ability to access output and input markets, production technology and capital sources, and the amount of capital owned. While external factors are support or technical and financial assistance from the government and private sector, economic conditions reflected from domestic and foreign market demand and technological advances in the business. One of the factors to see the development of small industry is to see the growth of its business. Business growth can be seen from production growth, sales growth, revenue growth and profit growth. 
Regulation of banking and taxation regulation in the theory of Hudson et al. (2001) and Munizu (2010) is an indicator of one of the external factor variables that can directly affect the success of the business. Munizu (2010), and Alimusa (2019) stated that the position of external factors is equivalent to the internal factor of business actor's performance. To limit the discussion in this study, some research variables used are limited.

Banking regulation is a regulation related to banking established by Bank Indonesia to influence the economic units. The banking regulation used in this study is a banking policy specifically intended for SMEs to improve the competitiveness of SMEs. The banking regulation is measured by policies on the imposition of loan interest rates, the ease of submitting loans, and the speed with which credit disbursements are channelled by banks (Bank Indonesia, 2014; Mishkin, 2011; Brigham and Houston, 2014; Horne and Wachowiz, 2013).

Taxation regulation is a regulation related to taxation established by the government to influence economic units. Taxation regulation used in this research is taxation policy specifically intended for SMEs to improve the competitiveness of SMEs. In this study the tax regulations are measured by tax assessment for SMEs, simplification of tax procedures, ease of tax process and tax transparency (Fiscal Policy Agency, 2014). Performance is how the work process to generate job performance. Performance can be measured using three indicators, business owner motivation, management skills, and shared vision (Hudson et al., 2001; Munizu, 2010; Luthans, 2005; Mathis and Jackson, 2014). Financial inclusion or smart financial behaviour is a program of the Financial Services Authority (OJK) launched for the public to recognize, use or obtain banking services.

Financial inclusion provides simple, easy-to-understand financial products to meet the needs of the community. Indicators that are used in financial inclusion according to OJK (2012) include:

1) availability of access is to measure the ability of the use of formal financial services in terms of physical affordability and price;

2) Usage: measures the actual used capability of financial products and services (regularity, frequency and duration of use);

3) Quality: Measures whether the attributes of financial products and services meet customers' satisfaction;

4) Welfare: Measuring the impact of financial services on the level of life of service users. The success of a business is a condition that shows business growth.

The success of the business can be reviewed from several aspects including value added, business unit, labour, productivity and export value. In this research, the success of the business is measured by capital increase, business scale improvement, profit improvement and business management improvement (Steinhoff, 1993; Drucker, 1996; Carter and Jones, 2012). 


\subsection{Hypothesis Formulation}

Abereijo and Fayomi (2005), achieving business success requires an innovative approach to the financing of SMEs around the world, especially private equity financing, so as to identify best practices and lessons to be learned. Abereijo and Fayomi (2005), found that there are still many obstacles faced by SMEs in the filing of credit for the development of its business. According to Asikhia (2009), Obasan and Arikewuyo (2012), the attitude of business owners, especially SMEs in relation to financial institutions (banking), can determine the success of SMEs business. Therefore, Asikhia (2009), Obasan and Arikewuyo (2012), recommends that the effectiveness of bank management, especially microfinance is one of SME development strategies. Financial institutions are expected to provide good financial and business guidance or education for SMEs.

Akingunola (2011), Hassan and Olaniran (2011) stated that the relationship between SME financing and economic growth in a country shows a significant positive relationship between SME financing and economic growth through increased investment. Ease of access to bank credit in SMEs has a positive impact on the growth of SMEs (Ahiawodzi and Adade, 2012). The role of government to intervene through policies and programs to promote SME funding and reduce lending rates will stimulate and enhance the development and sustainability of SMEs. Manini et al. (2016) stated that the role of financial institutions (banking) has a positive impact on the development of SMEs.

According to Adebisi and Gbegi (2013), the existence of government tax policy for SMEs impacts the survival of SMEs. Taxes are an important source of funds for economic development and social services, however, often the problems faced by small business groups are the existence of a negative relationship between tax and the ability to expand business. SMEs are often faced with high tax rates, burdened with some types of taxes, complicated tax rules and lack of education about taxation. The results of Adebisi and Gbegi (2013) study are as follows: 1) the relationship between progressive tax and SME survival is significant; 2) the relationship between SME size and ability to pay taxes is not significant. The development and operation of SMEs have an economic impact on a country. There is a significant relationship between the size of SMEs, the ability to pay taxes, the application of some types of taxes and the viability of SMEs. Therefore, the researchers stated that the imposition of several types of taxes has a positive effect significantly affecting the survival and growth of SMEs.

SME financing from the banking sector is essential for improving the performance of SMEs. Factors affecting SME financing are collateral issues, high credit interest rates, and lack of government interference for SMEs (Harash et al., 2014). According to Kira (2013), and Katua (2014), financing small and medium enterprises is essential for the promotion of sustainable economic growth and poverty reduction, government intervention through policies and programs to 
promote SME funding and reduce loan interest rates. This will stimulate and improve the performance of SMEs. According to Aberejo and Fayomi (2005), Akingunola (2011), Hassan and Olaniran (2011), Kira (2013), Katua (2014), Soomro and Aziz (2014), Harash et al. (2014), and Manini et al. (2016), the existence of government policy on banking towards SMEs has a positive impact on the performance of SMEs.

According to Ojeka (2011), it is stated that SMEs' perceptions on government tax policies that support small businesses (easy access to taxes, and simplification of tax procedures) have a significant positive effect on SME performance. Increased tax policies that support SMEs will improve the performance of SMEs.

Eniola and Entebang (2016), they state that there is a significant positive effect of SME's performance on financial inclusion of SME actors. Improving the performance of SMEs can improve knowledge about finance and ultimately SMEs will have strong competitiveness in the economy. Knowledge of banking services and other financial institutions becomes very important for the development of SMEs. According to Eniola and Entebang (2016), the knowledge of manager, innovation, manager behaviour, intellectual capital, and the concern of organization members have a significant effect on SMEs performance. Furthermore, the performance of SMEs has a significant positive effect on financial inclusion of SMEs.

According to Terzi (2015), the financial inclusion indicator consisting of the ease of cost and distance to access, and the type of services accessible are factors that can influence the success of SMEs. The result of Terzi's research (2015) shows that the increasing inclusions of SME finance can contribute positively to the success of SMEs and ultimately can improve the financial stability of a country. Irmawati et al. (2013), Salman et al. (2015) stated that the financial inclusion dimension includes mobile banking, banking services and banking penetration, have a significant positive effect on SME growth. According to Simiyu and Oloko (2015), the availability of Automated Teller Machines (ATM), Point of Sale Terminal (POS) and deposit machines as well as addition of branch offices in rural area, which are a dimension of financial inclusion, will improve financial services to the community in supporting growth and competitiveness of SMEs.

Mashenene and Rumanyika (2014) stated that business performance can be measured by initial capital ownership, management capability, age of business actors, education level, ethnicity, availability of credit from banking, and motivation. The results of Mashenene and Rumanyika research (2014), show that the initial capital ownership, availability of credit, age of actors and demand have no effect on SME's growth. While the ability of management, level of education, ethnic and motivation of business actors have a significant positive effect on SME growth. Sudiarta et al. (2014) states that each stage of company growth is the result of two environments in which the company conducts its business, namely internal and 
external environment. Important external factors affecting company growth are industry and markets, competing companies, and the economic climate while critical development factors for corporate growth are management ability, motivation, ownership or ownership structure. According to Sudiarta et al. (2014), internal factors of the company's environment consist of management ability, motivation, ownership or ownership structure able to increase the growth of small business. According to Subhan et al. (2014), there is a significant positive influence of vision and mission of SMEs as an indicator of SMEs performance on the development of SMEs' exports as supporting economic development. The results showed that the vision of SMEs mission and innovation of SMEs as indicators of SMEs performance has a significant positive effect on SME export growth.

According to Hassan and Olaniran (2011), Quaye et al. (2014), the financing of small and medium enterprises is essential for the promotion of sustainable economic growth and poverty reduction through the empowerment of SMEs. Quaye et al. (2014), identifies factors related to government policy on loan collateral issues, ease of credit terms, credit lending rates, and high technological development in credit services to SMEs. Quaye et al. (2014) states that credit collateral problems, ease of credit conditions, credit lending rates, and high technological development in credit services have a significant positive effect on SMEs' performance and SMEs' development. Shah et al. (2011), states that the success or growth of SMEs is influenced by the performance of SMEs. The results of Shah et al. (2011) show that the performance of SMEs has a significant positive effect on SME growth.

Government services that include banking regulations and tax policies have a significant positive effect on the growth or success of SMEs. Mashenene and Rumanyika's research (2014) shows that the management ability of business actors as performance indicators has a significant positive effect on SMEs' growth. The performance of SMEs is influenced by banking regulation through low interest rates, as well as easy credit procedures for small and medium enterprises (Akingunola, 2011; Mishkin, 2011; and Katua, 2014). Subhan et al. (2014) undertook research on the influence of SME mission vision and SME innovation as an indicator of SME performance and the influence of SMEs performance on SME export development as an indicator of SME success. The results of Subhan et al. (2014) showed that SMEs' vision and SME innovation have a significant positive effect on SMEs' export growth.

Ojeka (2011), and Adebisi and Gbegi (2013), examine the effect of tax policies on SMEs' performance. The results obtained that the tax policy which includes the determination of tax rates, ease of services and tax transparencies for SMEs have a significant positive influence to the performance of SMEs. While Shah et al. (2011) examines the effect of SMEs on the success or growth of SMEs. The results of Shah et al. (2011) show that the performance of SMEs has a significant positive effect on SMEs' growth. Mashenene and Rumanyika (2014) research results show that the management ability of business actors as performance indicators have a significant 
positive effect on SME growth. The performance of SMEs is influenced by the tax policy that includes the establishment of tax rates, ease of services and tax transparency for SMEs (Ojeka, 2011; Adebisi and Gbegi, 2013). Meanwhile, according to Shah et al. (2011), the success or growth of SMEs in addition to being influenced by the performance of business actors is also influenced by government services that include banking and fiscal policy. The results of Shah et al. (2011), indicates that government services that include banking and fiscal policies have a significant positive effect on the growth or success of SMEs.

Ahiawodzi and Adade (2012), Eniola and Entebang (2015), examines the relationship between government policy (which includes tax rate policy and banking policy i.e., credit interest rate) and the success of small and medium enterprises (SMEs). The results show that government policies related to lending rates have a positive relationship with the success of SMEs. Eniola and Entebang (2016) conducted a study on the effect of SMEs' performance on financial inclusion of SMEs' actors. Through improving the performance of SMEs, they can improve their knowledge of finance and ultimately SMEs will have a strong competitiveness in the economy. Knowledge, innovation, managers' behaviour, intellectual capital, and the care of members of the organization are vital elements for organizational success.

Knowledge of banking services and other financial institutions becomes very important for the development of SMEs. The results of this study indicate the existence of managerial knowledge, innovation, managers' behaviour, intellectual capital, and significant organizational members' concern on SME's performance. The next test is the performance of SMEs that are positive towards the financial inclusion of SME actors. Terzi (2015) states that an increase in financial inclusion of SMEs can contribute positively to the success of SMEs and ultimately can improve the stability of a country.

Ojeka (2011) examines the effect of tax policies on the performance of SMEs. The results of the study found that tax policy for SMEs has a significant positive effect on SMEs' performance. Recommended tax regulations for SMEs are increasing tax incentives through reduced tax rates and improving taxpayer support services to SMEs (Ojeka, 2011). According to Eniola and Entebang (2016), through improving the performance of SMEs, it can improve the knowledge of SMEs on financial and ultimately SMEs will have a strong competitiveness in the economy. Knowledge, innovation, managers' behaviour, intellectual capital, and the care of members of the organization are very important factors for organizational success in order to gain a competitive advantage. Knowledge of banking services and other financial institutions becomes very important for the development of SMEs. The results showed that the managers' knowledge, innovation, managers' behaviour, intellectual capital, and awareness of members of the organization have a significant positive effect on the performance of SMEs. Further tests obtained that the performance of SMEs has a significant positive effect on financial inclusion SME actors. The results of Terzi's research (2015) show that the increasing inclusion of financial SME actors 
can contribute positively to the success of SMEs and ultimately can improve the financial stability of a State.

Access to financial services is an indicator of financial inclusion and an important requirement of community involvement in an economic system that can improve the welfare of the community (Terzi, 2015, Salman et al., 2015; Ene and Inemesit, 2015; Salman et al., 2015; Alaaraj and Bakri, 2020). According to Eniola and Entebang (2016), by improving the performance of SMEs can improve the knowledge of SMEs on financial players that ultimately SMEs will have a strong competitiveness in the economy. Knowledge, innovation, manager behaviour, intellectual capital, and management skills are crucial factors for organizational success in order to gain a competitive advantage. Knowledge of banking services and other financial institutions becomes very important for the development of SMEs. The results showed that the knowledge manager, innovation, manager behaviour, intellectual capital, and awareness of members of the organization have a significant positive effect on the performance of SMEs. Further tests obtained that the performance of SMEs have a significant positive effect on financial inclusion. Furthermore, Terzi (2015) and Alimusa (2019) in their studies show that increasing SME financial inclusion as measured by the availability of banking access and the welfare of users of banking services can contribute positively to the success of SMEs and ultimately can improve the financial stability of a country. Based on the results of previous researches, the research hypotheses are formulated as follows:

$H_{1}$ : Improved banking regulation will increase business success.

$\mathrm{H}_{2}$ : Improved tax regulations will increase business success.

$\mathrm{H}_{3}$ : Improved banking regulations will improve performance.

$H_{4}$ : Improved tax regulations will improve performance.

$H_{5}$ : Improved performance will improve financial inclusion.

$H_{6}$ : Improved financial inclusion will increase business success.

$H_{7}$ : Improved performance will improve business success.

$H_{8}$ : Improved regulation of mediated banking performance will increase business success.

$H_{9:}$ Improved tax regulation mediated by performance will increase business success.

$H_{10:}$ Improved banking regulation mediated by performance and financial inclusion will increase business success.

$H_{11}$ : Improved tax regulations mediated by performance and financial inclusion will increase business success.

$H_{12}$ : Improved performance of mediated financial inclusion will improve business success.

\section{Research Methods}

The population used in this study is batik SMEs located in Wijirejo Village, Pandak District, Bantul Regency of Yogyakarta, Indonesia. The selected population criteria 
as respondents are SMEs who have been operating for more than one year and have bank accounts. The selection of respondents was determined on the grounds that within that time the batik SMEs practitioners were deemed to be able to feel the benefits of financial inclusion and the implementation of social responsibility by large companies to their business. So they can provide feedback on banking regulation and taxation in relation to the performance and success of its business.

The determination of the sample in this study uses saturated or census sampling. According to Ferdinand (2014), saturated or census samples are sampling techniques when all members of the population are used as samples. Because in this study the entire population had the same opportunity to be sampled, the sampling approach used is the census approach. Hypothesis support in this research performed using partial least square analysis tool (PLS) which is often called variance or component based structural equation modelling. The PLS program used to analyse data is WarpPLS 5.0. The reason for using Warp-PLS is because the program is able to identify nonlinear relationships between latent variables and correct path coefficient values based on relationships among variables. Since most relationships between variables are nonlinear, Warp-PLS can find the actual relationship between latent variables in SEM analysis.

\section{Results and Discussion}

The hypotheses tested in this study include: 1) the influence of banking regulation (RB) directly on the success of the business (SB), 2) the influence of tax regulations (RT) directly on business success (SB), 3) the influence of banking regulations on performance $(\mathrm{P}), 4)$ the influence of tax regulations $(\mathrm{RT})$ on performance $(\mathrm{P}), 5)$ the effect of performance $(\mathrm{P})$ to the financial inclusion $(\mathrm{FI}), 6)$ the influence of financial inclusion (FI) on business success $(\mathrm{SB}), 7$ ) the effect of performance $(\mathrm{P})$ on business success $(\mathrm{SB}), 8)$ the influence of banking regulation on business success through business actor performance 9) the influence of tax regulation on business success through business actors performance 10) banking regulation on business success through business actors 'performance and financial inclusion, 11) influence of tax regulation on business success through business actors' performance and financial inclusion, 12) influence of performance on business success through financial inclusion.

Table 1. Coefficient of Direct Effect Line and Hypothesis Testing

\begin{tabular}{lllll}
\hline Hypothesis & Direct Effect & Coefficient Path & p-value & Result \\
\hline $\mathrm{H}_{1}$ & $\mathrm{RB} \rightarrow \mathrm{SB}$ & 0.132 & 0.124 & Not significant \\
$\mathrm{H}_{2}$ & $\mathrm{RT} \rightarrow \mathrm{SB}$ & 0.098 & 0.228 & Not significant \\
$\mathrm{H}_{3}$ & $\mathrm{RB} \rightarrow \mathrm{P}$ & 0.282 & 0.000 & Significant \\
$\mathrm{H}_{4}$ & $\mathrm{RT} \rightarrow \mathrm{P}$ & 0.167 & 0.043 & Significant \\
$\mathrm{H}_{5}$ & $\mathrm{P} \rightarrow \mathrm{FI}$ & 0.187 & 0.025 & Significant \\
$\mathrm{H}_{6}$ & $\mathrm{FI} \rightarrow \mathrm{SB}$ & 0.192 & 0.006 & Significant \\
$\mathrm{H}_{7}$ & $\mathrm{P} \rightarrow \mathrm{SB}$ & 0.210 & 0.002 & Significant \\
\hline
\end{tabular}

Source: Result of processed warp-PLS (2018). 
Based on hypothesis test result $\left(\mathrm{H}_{1}\right)$ is rejected which means that the improvement of banking regulation is directly unable to increase business success. Empirically, this research shows that the improvement of banking regulation for batik SMEs in Wijirejo Village, Pandak District, Bantul Regency of Yogyakarta, Indonesia, has not been able to improve the success of SME's business in that area. The result of analysis of the direct effect of taxation regulation to the success of the business is obtained by the coefficient value of 0.098 with p-value $0.228>0.05$. Based on the results of testing hypotheses, $\left(\mathrm{H}_{2}\right)$ is empirically rejected. The result can be interpreted that the taxation regulation is not directly able to improve business success. The results can be interpreted that the improved tax regulations for SMEs batik was unable to improve the success of its business.

Table 2. Indirect Influence and Hypothesis Testing

\begin{tabular}{lcllll}
\hline Hypothesis & $\begin{array}{l}\text { Independent } \\
\text { Variables }\end{array}$ & $\begin{array}{l}\text { Mediation } \\
\text { Variables }\end{array}$ & $\begin{array}{l}\text { Dependent } \\
\text { Variables }\end{array}$ & p-value & Information \\
\hline $\mathrm{H}_{8}$ & $\mathrm{RB}$ & $\mathrm{P}$ & $\mathrm{SB}$ & 0.023 & Full Mediation \\
$\mathrm{H}_{9}$ & $\mathrm{RT}$ & $\mathrm{P}$ & $\mathrm{SB}$ & 0.035 & Full Mediation \\
$\mathrm{H}_{10}$ & $\mathrm{RB}$ & $\mathrm{P}, \mathrm{FI}$ & $\mathrm{SB}$ & 0.016 & Full Mediation \\
$\mathrm{H}_{11}$ & $\mathrm{RT}$ & $\mathrm{P}, \mathrm{FI}$ & $\mathrm{SB}$ & 0.033 & Full Mediation \\
$\mathrm{H}_{12}$ & $\mathrm{P}$ & $\mathrm{FI}$ & $\mathrm{SB}$ & 0.042 & Partial \\
& & & & & Mediation \\
\hline
\end{tabular}

Source: Processed warp-PLS (2018).

The coefficient value of bank regulatory effect on business performance is 0.282 with p-value $0.000<0.05$. Based on the result of hypothesis test, $\left(\mathrm{H}_{3}\right)$ is accepted which means that the improvement of banking regulation is able to improve performance directly. This means that the improved regulation of banking on SMEs batik can improve business performance. The coefficient value of the influence of tax regulation effect on the performance is 0.167 with $\mathrm{p}$-value $0.042<0.05$. The result of hypothesis testing $\left(\mathrm{H}_{4}\right)$ is accepted which indicates that the improvement of tax regulation can improve the performance of business actor. It can be interpreted empirically that the improved regulation taxation of SMEs batik is able to improve the performance of SMEs.

The analysis result of performance influence on financial inclusion of business actor obtained by coefficient value is 0.187 with p-value $0.025<0.05$. Based on the result of hypothesis testing, $\left(\mathrm{H}_{5}\right)$ is accepted which indicates that the improvement of performance can increase financial inclusion of business actor. It can be interpreted empirically that the better performance of SMEs batik the more they are able to increase financial inclusion of business actors. Based on the result of hypothesis testing, the influence of financial inclusion on the success of the business obtained by coefficient value of 0.192 with p-value $0.006<0.05$. Hence the result of hypothesis testing, $\left(\mathrm{H}_{6}\right)$ is accepted which can be interpreted that improvement of financial inclusion is able to increase business success. It can be empirically 
interpreted that the improvement of financial inclusion of SMEs batik is able to improve the success of its business.

The analysis result of direct effect of performance on business success obtained by coefficient value is 0.210 with p-value $0.002<0.05$. Based on the test results, the hypothesis $\left(\mathrm{H}_{7}\right)$ is accepted which indicates that the improved performance can improve the success of the business. The result can be interpreted that the improvement of performance of SMEs is able to improve the success of its business. The result of $\mathrm{H} 8$ hypothesis testing is accepted indicating that the performance variable $(\mathrm{P})$ is able to fully mediate the influence of banking regulation $(\mathrm{RB})$ on business success (SB). Direct banking regulation has no significant effect on business success, but through performance mediation, realistically, banking regulation can influence business success. Empirically, this research accepted the hypothesis $\left(\mathrm{H}_{8}\right)$ which can be interpreted that the improvement of banking regulation of batik SMEs in Wijirejo Village, Pandak Sub-district, Bantul Regency mediated by the performance of business actors is able to increase business success.

Based on the results, this study has accepted the hypothesis $\left(\mathrm{H}_{9}\right)$ which means that improved tax regulation mediated by performance can improve business success. This result can be interpreted that the improvement of taxation regulation of SME actors cannot improve the success of SME batik business. However, mediated by performance variables, the improvement of taxation regulation can increase the success of batik business in Wijirejo Village, Pandak District, Bantul Regency.

Improving banking regulation (RB) is not able to increase business success. However, by using performance variable and financial inclusion as mediation variable, p-value $0.016<0.05$ is obtained. This shows that the result accepts hypothesis $\left(\mathrm{H}_{10}\right)$ which can be interpreted that improvement of banking regulation mediated by performance and financial inclusion can increase business success. Based on the results of this study it can be stated that the improvement of banking regulations directly is unable to improve the success of SMEs batik business. However, with the mediated performance and financial inclusion, improved banking regulation can improve the success of batik business.

The influence of taxation regulation (RT) is not directly able to increase the business success shown by the value of p-value $0.228>0.05$. However, with the variable of performance $(\mathrm{P})$ and financial inclusion $(\mathrm{FI})$ as the mediation variable, the influence of tax regulation (RT) on the business success (SB) obtained p-value $0.033<0.05$. Thus, hypothesis $\left(\mathrm{H}_{11}\right)$ is accepted. This indicates that improved taxation regulation mediated by performance and financial inclusion can improve business success. Therefore, it can be stated that the improvement of taxation regulation is not directly able to improve the success of business. However, mediated performance, financial inclusion, and tax regulation can improve the success of SME batik business. 
The result of hypothesis test shows that $\left(\mathrm{H}_{12}\right)$ is accepted, that means performance (P) mediated by financial inclusion can increase business success (SB). In this study, financial inclusion is partially mediated by effect of performance on business success. It is said to be partially mediated because without mediation of financial inclusion, performance variables are directly able to increase business success with greater coefficient value $(0.210)$ than if it is mediated by financial inclusion $(0.167)$. The p-value that directly influences performance on business success is 0.002 and if it is mediated by financial inclusion p-value is 0.042 . This means that performance is more capable of improving business success than mediated financial inclusion. Based on the results of testing in this study, it can be stated that improved performance mediated by financial inclusion can improve the success of batik business.

\section{Conclusion}

The determination of Bank Indonesia regulation on banking regulation for Small and Medium Enterprises is not a determining factor for the success of SME batik business in Wijirejo Village, Pandak District, Bantul Regency, Yogyakarta, Indonesia. This happens because the SMEs actors assume that banking regulations does not have any effect on the success of their business which always increases year after year. The result does not mean that the actors of batik SMEs ignore existing banking regulations, but avoid the risk of having debts (Salim, 2017). SMEs actors believe that the success of their business comes from self or called internal control focus. Government regulation on special tax regulation for Small and Medium Enterprises is not a determinant factor for the success of SME batik business, just as with the effect of banking regulation on business success. Similarly, respondents of batik SMEs tax regulations assume that existence of taxation regulation has nothing to do with their business success although the perpetrators of batik SMEs pay all taxes imposed on them.

Bank Indonesia's policy on banking regulation that is intended for Small and Medium Enterprises is a determinant factor for the increasing performance of SMEs as evidenced by clear mission, vision, good management capability and good motivation. Implementation of banking regulations for SMEs through the determination of loan interest rates, easy credit application and the speed of credit process make the SMEs actors have more time to manage their business so as to achieve better performance.

Determination of government regulations on tax regulations that are intended for Small and Medium Enterprises is a determinant factor for the increasing performance of SMEs as shown by clear mission vision, good management skills and good motivation. The tax regulations through the determination of tax rates for SMEs, the ease of tax access, the simplification of tax procedures and the transparency of taxes affect SMEs and make them more focused in running their business because they will not have any trouble with tax. 
Implementation of a firm mission vision, good management skills and high work motivation of batik SMEs in Wijirejo Village becomes the determining factor to improve SMEs' knowledge of banking especially in finance (financial inclusion). Some SMEs actors in the last two years have started to do business with non-cash transactions. The knowledge about banking (financial literacy) of batik SMEs in Wijirejo Village, one of them through the use of banking products and services becomes the decisive factor to increase the success of their business. More and more batik SMEs willing to conduct non-cash business transactions impact on increasing capital, profits and customers from various regions. Most of the batik SMEs actors especially the next generation, today non-cash transactions have been started to be widely conducted to make their business grow.

Batik SMEs actors still run their business traditionally, but they have firm vision and mission, high motivation and use the ability of management as a determinant factor of increasing the business development. This has an impact on capital improvement, business scale, profit and business management that ultimately can improve the success of the business.

The implementation of Bank Indonesia regulation concerning banking regulation for Small and Medium Enterprises especially for batik SMEs supported by business management with its own cash feature becomes the determining factor to increase the success of the business. SMEs actors feel the benefits of the existence of banking policies intended for SMEs accompanied by proper business management that can improve the development of business. Implementation of government regulation concerning tax regulation for Small and Medium Enterprises especially for perpetrator of SME batik, supported by business management having its own cash feature becomes the determining factor to increase the success of its business. Performer SME batik, feel the benefits of the tax regulations (fiscal policy) is intended for SMEs accompanied by proper business management can improve business development.

Banking regulation applied by Bank Indonesia for SMEs through credit interest rates, easy credit application and speed of credit process supported by good business management and good financial knowledge become the determining factor in increasing capital, business scale, profit and management business for batik SMEs. Tax regulations applied by the government for SMEs through the determination of tax rates for SMEs, the ease of tax access, the simplification of tax procedures and the transparency of taxes supported by good business management and financial knowledge (financial literacy) are determining factors in increasing capital, profit and business management for batik SMEs in. Batik SMEs still run their business traditionally, however, by applying firm vision and mission, high motivation and good use of management skills and supported by financial literacy, SMEs are the determinants of increasing business development. 


\section{Recommendations}

The assessment of batik SMEs in Wijirejo Village, Indonesia in relation to banking policy (banking regulation) and taxation regulation in general is good, but there are still some batik SMEs who are reluctant to utilize the regulation. Therefore, continuous education and assistance from the government, especially local governments on banking regulations and tax regulations for batik SMEs are needed to improve bankable in Wijirejo Village, Indonesia community. Assessment of batik SMEs on financial literacy or financial inclusion in general is good, but the understanding of batik SMEs towards financial inclusion is still low. This is evident from their reluctance to use banking facilities that are very useful to support and facilitate business. Seeing such conditions and the increasing number of customers from various circles, it is necessary to have financial and taxation literacy for the community of Wijirejo Village, Indonesia.

The findings of this study provide input to the next researcher to be able to add the identity variable or locus of internal control as a variable that can affect the success of small and medium enterprises. Subsequent research related to the success of SMEs, using the concept framework as in this study is expected to add indicators in each variable that can represent the condition of the object of research. For example, technological capabilities of business actors, awareness of the existence of change management (disruption) can be added as indicators of business actors' performance.

\section{References:}

Alimusa, L.O. 2019. Determinant of Muslim Entrepreneurs Decisions on Sharia Bank Financing and Its Effect on Business Performance. IKONOMIKA: Jurnal Ekonomi dan Bisnis Islam, 4(1), 71-84.

Alaaraj, H., Bakri, A. 2020. The Effect Financial Literacy on Investment Decision Making in Southern Lebanon. International Business and Accounting Research Journal, 4 (1), 37 43.

Abereijo, O.A., Fayomi, O. 2009. Innovative Approach to SME Financing in Nigeria: A Review of Small and Medium Industries Equity Investment Scheme (SMIEIS). Journal of Social Sciences, 11(3), 219-227.

Adebisi, J.F., Gbegi, D.O. 2013. Effect of Multiple Taxation on the Performance of Small and Medium Scale Business Enterprises. (A Study of West African Ceremics Ajeokuta, Kogi State). Mediterranean Journal of Social Sciences, 4(6), 45-62.

Ahiawodzi, A.K., Adade, T.C. 2012. Access to Credit and Growth of Small and Medium Scale Enterprises in the Ho Municipality of Ghana. British Journal of Economics, Finance and Management Sciences, 6(2), 34-51.

Akingunola, R.O. 2011. Small and medium scale enterprises and economic growth in Nigeria: An assessment of financing options. Pakistan Journal of Business and Economic Review, 2(1).

Ameyaw, B., Korang, J.A., Twum, E.T., Asante, I.O. 2016. Tax Policy, SMES Compliance, Perception and Growth Relationship in Ghana: An Empirical Analysis. British Journal of Economics, Management \& Trade, 11(2), 1-11.

Asikhia, O.U. 2009. Attitudinal response of small and medium scale business owners to 
microfinance banking in Nigeria. European Journal of Social Sciences, 11(4).

Atawodi, O.W., Ojeka, S.A. 2012. Relationship between Tax Policy, Growth of SMEs and the Nigerian Economy. International Journal of Business and Management, 7(13), 125-135.

Bank Indonesia. 2014. Booklet Keuangan Inklusif. Jakarta. Departemen Pengembangan Akses Keuangan dan UMKM.

Brigham, E.F., Houston, J.F. 2014. Essentials of Financial Management. 3th Edition. Cengage. Asia.

Carter, S., Jones, E.D. 2012. Enterprise and Small Business Principles, Practice and Policy. Pearson.

Chen, J. 2006. Development of Chinese small and medium-sized enterprises. Journal of Small Business and Enterprise Development, 13(2), 140-147.

Drucker, P.F. 1996. Innovation and Entrepreneurship. Perfect Bound.

Ene, E.E., Inemesit, U.A. 2015. Impact of microfinance in promoting Financial Inclusion in Nigeria. Journal of Business Theory and Practice, 3(2), 139. www.scholink.org/ojs/index.php/jbtp.

Eniola, A.A., Entebang, H. 2014. SME firms performance in Nigeria: Competitive advantage and its impact. International Journal of Research Studies in Management, 3(2), 75-86.

Eniola, A.A., Entebang, H. 2015. SME firm performance-financial innovation and challenges. Procedia - Social and Behavioral Sciences, 195, 334-342.

Eniola, A.A., Entebang, H. 2016. Financial literacy and SME firm performance. International Journal of Research Studies in Management, 5(1), 31-43.

Folorunso, O.O., Abodunde, S.M., Kareem, T.S. 2015. Small and medium scale enterprises and economic growth and development in nigeria: an empirical investigation. International Journal in Management and Social Science, 03(04), 459-469.

Harash, E., Al-Timimi, S., Alsaadi, J. 2014. The influence of finance on performance of Small and Medium Enterprises (SMES). International Journal of Engineering and Innovative Technology (IJEIT), 4(3), 161-176.

Hassan, M.A., Olaniran, S.O. 2011. Small business entrepreneurs through assistance institutions: the role of industrial development centre, Osogbo, Nigeria. International Journal of Business and Management, 6(2), 213-226.

Horne, J.C., Wachowiz, J.M. 2013. Fundamentals of Financial Management. Prentice Hall.

Hudson, M., Smart, A., Bourne, M. 2001. Theory and practice in SME performance measurement systems. International Journal of Operations \& Production Management, 21(8), 1096-1115.

Irmawati, S., Damelia, D., Puspita, D.W. 2013. Model inklusi keuangan pada UMKM Berbasis Pedesaan. Journal of Economics and Policy, 6(2), 103-213.

Katua, N.T. 2014. The Role of SMEs in employment creation and economic growth in selected countries. International Journal of Education and Research, 2(12).

Kira, A.R. 2013. Determinants of financing constraints in East African countries' SMEs. International Journal of Business and Management, 8(8).

Mishkin, F.S. 2011. The Economics of Money, Banking and Financial Markets. 8th Edition. Pearson Education.

Manini, M.M., Abdillahi, U.A., Wanyama, K., Simiyu, J. 2016. Effect of business financing on the performance of small and medium enterprises in Lurambi Sub-County, Kenya. European Journal of Business and Management, 8(2), 1-21.

Mashenene, R.G., Rumanyika, R. 2014. Business constraints and potential growth of small and medium enterprises in Tanzania: A Review. European Journal of Business and Management, 6(32), 72-80. 
Munizu, M. 2010. Pengaruh faktor-Faktor eksternal dan internal terhadap kinerja usaha mikro dan kecil (UMK) di Sulawesi Selatan. Jurnal Manajemen dan Kewirausahaan, 12(1), 33-41.

Ndesaulwa, A.P. 2016. The Impact of innovation on performance of Small and Medium Enterprises (SMEs) in Tanzania: A Review of Empirical Evidence. Journal of Business and Management Sciences, 4(1), 1-6.

Ojeka, S.A. 2011. Tax policy and the growth of SMEs: Implications for the Nigerian economy. Research Journal of Finance and Accounting, 2(2), 125-135.

Obasan, K.A., Arikewuyo, K.A. 2012. The effect of pre-post bank consolidation on the accessibility of finance to SMEs in Nigeria. Business and Management Research, 1(3), 108-120.

Quaye, I., Abrokwah, E., Sarbah, A., Osei, J.Y. 2014. Bridging the SME financing gap in Ghana: The Role of Microfinance Institutions. Journal of Business and Management.

Salim, U. 2011. Manajemen keuangan strategik: Panduan memperbaiki kinerja keuangan dan profit. UB Press. Universitas Brawijaya. Malang.

Salman, A., Oyebiyi, A., Ogechi, E. 2015. Influence of financial inclusion on small and medium enterprises growth and development in Nigeria. International Journal in Management and Social Science, 3(4), 390-401.

Shah, A.A., Mehmood, T., Hashmi, M.A., Syed Md. S., Shaikh, F.M. 2011. Performance of SMEs in export growth and its impact on economy of Pakistan. International Journal of Business and Management, 6(7), 287-297.

Simiyu, C.N., Oloko, M. 2015. Mobile money transfer and the growth of small and medium sized enterprises in Kenya a case of Kisumu City, Kenya. International Journal of Economics, Commerce and Management, 3(5), 1056-1081.

Steinhoff, D., Burgess, J.F. 1993. Small business management - fundamentals, McGraw Hill.

Subhan, Qazi Abdul, Mahmood, Tahir and Sattar, Abdul. 2014. Innovation and economic development: A case of small and medium enterprises in Pakistan. Pakistan Economic and Social Review, 52(2), 159-174.

Sudiarta, I.P.L., Kirya, I.K., Cipta, I.W. 2014. Analisis faktor-faktor yang mempengaruhi kinerja usaha mikro kecil dan menengah di Kabupaten Bangli. e-journal Bisnis Universitas Pendidikan Ganesha, 2(1).

Terzi, N. 2015. Financial inclusion and Turkey. Academic Journal of Interdisciplinary Studies, 4(1), S2, 269-276.

Widayani, A., Rahmawati, I., Normawati, R.A. 2019. On The Role of Information Technology Micro, Small and Medium Enterprises in Kota Blitar. Finance, Accounting and Business Analysis, 1(2), 188-194. 